\title{
Uji Aktivitas Antibakteri Ekstrak Kasar Umbi Sarang Semut (Myrmecodia pendens) Dibanding dengan Klorheksidin terhadap Streptococcus sanguinis
}

\author{
Fathimah Azzahra Attamimi, ${ }^{1}$ Rovina Ruslami, ${ }^{2}$ Ani Melani Maskoen ${ }^{3}$ \\ ${ }^{1}$ Fakultas Kedokteran Gigi Universitas Padjadjaran, ${ }^{2}$ Departemen Farmakologi dan Terapi Fakultas Kedokteran \\ Universitas Padjadjaran, ${ }^{3}$ Departemen Biologi Oral Fakultas Kedokteran Gigi Universitas Padjadjaran
}

\begin{abstract}
Abstrak
Streptococcus sanguinis merupakan bakteri pionir penyebab plak gigi. Penggunaan obat kumur klorheksidin merupakan tindakan untuk mengontrol pembentukan plak gigi, namun karena efek sampingnya, klorheksidin tidak dapat digunakan untuk jangka panjang. Umbi sarang semut (Myrmecodia pendens) merupakan tanaman obat yang memiliki banyak aktivitas biologis untuk kesehatan. Penelitian ini bertujuan menguji aktivitas antibakteri ekstrak kasar umbi sarang semut terhadap bakteri $S$. sanguinis dibandingkan dengan klorheksidin dan pengaruh pemberian konsentrasinya terhadap kematian sel bakteri. Metode penelitian menggunakan uji Kirby-Bauer untuk menentukan diameter hambat pertumbuhan bakteri, dilanjutkan dengan uji MIC untuk mengetahui nilai MIC dari sampel dan pengaruhnya terhadap kematian sel bakteri. Penelitian dilakukan pada bulan Agustus-Oktober 2015 di Laboratorium Kimia Organik Universitas Padjadjaran Hasil uji Kirby-Bauer ekstrak kasar umbi sarang semut menunjukkan aktivitas antibakteri. Zona hambat yang dihasilkan oleh ekstrak kasar tidak berbeda signifikan dengan klorheksidin (12 mm vs $15 \mathrm{~mm}, \mathrm{p}>0,05)$. Nilai MIC ekstrak kasar berada diantara 9,77 ppm dan 19,53 ppm, nilai ini lebih kecil dibanding dengan klorheksidin, yaitu sebesar 1,935 ppm. Selain itu, terdapat korelasi positif dan kuat antara konsentrasi ekstrak kasar dan kematian sel bakteri $S$. sanguinis $(r=0,867)$. Dapat disimpulkan ekstrak kasar umbi sarang semut memiliki efek antibakteri lebih kecil dibanding dengan klorheksidin. Peningkatan konsentrasi eksrak kasar umbi sarang semut memiliki korelasi positif dan kuat terhadap peningkatan kematian sel bakteri S. sanguinis. [MKB. 2017;49(2):94-101]
\end{abstract}

Kata kunci: Antibakteri, ekstrak kasar, klorheksidin, S. sanguinis, umbi sarang semut

\section{Antibacterial Activity Test of Ant Nest Tuber (Myrmecodia Pendens) Crude Extract against Streptococcus Sanguinis Compared to Chlorhexidine}

\begin{abstract}
Streptococcus sanguinis is a pioneer bacterium that causes dental plaque formation. The use of chlorhexidine mouthwash is one of the treatments to control dental plaque. However, due to its side effects, chlorhexidine cannot be used in a long period. Ant nest tuber (Myrmecodia pendens) is one of the medicinal plants with variousbiological activities that are beneficial to human health. The purpose of this study was to examine the antibacterial activity of ant nest tuber crude extract against bacteria S. sanguinis compared to chlorhexidine and measure the effect of increased concentration on bacterial cell death. This study was conducted using KirbyBauer method to measure the diameter of bacterial growth inhibition in August-October 2015 at the Organic Chemistry Laboratory of Universitas Padjadjaran. The MIC was then measured to determine the MIC values of the sample and the effect on bacterial cell death. Kirby-Bauer test showed that the inhibition zone produced by crude extract was not significantly different from the one produced by chlorhexidine (12 mm vs $15 \mathrm{~mm}, \mathrm{p}>0.05$ ) when both were used to inhibith the growth of S. sanguinis. The MIC value of crude extract was between 9.77 ppm and $19.53 \mathrm{ppm}$, smaller than the MIC value of the chlorhexidine of $1.93 \mathrm{ppm}$. In addition, there was a positive and strong correlation ( $r=0.867)$ between the concentration of crude extract and S. sanguinis cell death. Hence, crude extract from ant nest tuber has a lower antibacterial effect than chlorhexidine in inhibiting the growth of S. sanguinis. Additionally, there is a strong correlation between the increased concentration of crude extract and increased S. sanguinis cell death. [MKB. 2017;49(2):94-101]
\end{abstract}

Key words: Antibacterial, ant nest tuber, chlorhexidine, crude extract, S. sanguinis

Korespondensi: Fathimah Azzahra Attamimi, drg, Fakultas Kedokteran Gigi Universitas Padjadjaran, E-mail: a.fathimah@ yahoo.com 


\section{Pendahuluan}

Penyakit infeksi pada rongga mulut merupakan salah satu penyakit yang paling sering terjadi pada manusia. Infeksi pada rongga mulut juga sering kali dihubungkan dengan penyakit sistemik lainnya, seperti penyakit jantung dan diabetes melitus. ${ }^{1}$ Survei Riskesdas 2013 menunjukkan penyakit gigi dan mulut dengan prevalensi paling tinggi adalah karies dan penyakit periodontal.

Streptococcus sanguinis merupakan bakteri gram positif yang berperan sebagai bakteri pionir dalam kolonisasi bakteri dalam rongga mulut manusia. ${ }^{2}$ S. sanguinis berperan sebagai penjangkar untuk perlekatan mikroorganisme oral lain yang akan berkolonisasi di permukaan gigi, kemudian membentuk plak gigi dan berkontribusi terhadap perkembangan karies dan penyakit periodontal. ${ }^{3,4}$

Obat kumur yang bersifat bakteriostatik ialah merupakan salah satu tindakan untuk mengontrol pembentukan plak gigi. Klorheksidin merupakan standar emas perawatan plak dan karang gigi yang efektif baik terhadap gram negatif maupun positif, serta fakultatif anaerob maupun aerob. Penggunaan klorheksidin dalam jangka waktu lebih dari 2 minggu memiliki efek samping di antaranya menyebabkan rasa terbakar pada mukosa mulut, mengganggu indera perasa, pewarnaan gigi, erosi mukosa mulut, dan kekeringan pada rongga mulut. ${ }^{5}$

Tanaman merupakan sumber potensial untuk ditemukannya obat baru, hal ini dikemukakan oleh WHO. Salah satu tanaman obat yang belum teridentifikasi adalah umbi sarang semut (Myrmecodia pendens) yang memiliki potensi sebagai agen terapeutik baru. Umbi sarang semut merupakan tumbuhan epifit yang banyak tumbuh di daerah Papua. ${ }^{6}$

Ekstrak kasar umbi sarang semut memiliki efek antibakteri baik terhadap bakteri gram positif maupun negatif, di antaranya bakteri $S$. aureus, K. pneumoniae, dan $S$. dysentriae. ${ }^{7}$ Pada penelitian ini ekstrak kasar umbi sarang semut didapat melalui prosedur sokletasi dengan pelarut metanol yang dapat melarutkan baik senyawa polar maupun nonpolar sehingga diharapkan semakin banyak senyawa aktif yang terlarut dan dapat menghambat pertumbuhan bakteri $S$. sanguinis.

Penelitian ini bertujuan menguji aktivitas antibakteri ekstrak kasar umbi sarang semut terhadap bakteri $S$. sanguinis bila dibanding dengan klorheksidin dan pengaruh pemberian konsentrasinya terhadap kematian sel bakteri $S$. sanguinis.

\section{Metode}

Penelitian ini ialah eksperimen laboratorium. Penelitian ini dilakukan pada bulan AgustusOktober 2015 di Laboratorium Kimia Organik Universitas Padjadjaran. Pengujian aktivitas antibakteri ekstrak umbi sarang semut melalui Uji Kirby-bauer dan Uji MIC dilakukan 2 kali pengulangan (duplo). Sampel penelitian ini adalah ekstrak kasar umbi sarang semut dan klorheksidin. Strain bakteri yang digunakan pada penelitian ini adalah $S$. sanguinis ATCC 10556. Uji Kirby-bauer dilakukan melalui dua tahap, dimulai dengan melakukan peremajaan pada S. sanguinis ATCC 10556. Bakteri diremajakan dengan menumbuhkan bakteri pada media Muller Hinton Broth selama 24-48 jam dengan kecepatan pengocokan $150 \mathrm{rpm}$ pada suhu $37^{\circ} \mathrm{C}$. Kekeruhan harus memenuhi standar 0,5 Mc Farland. Tahap kedua adalah uji sensitivitas bakteri terhadap sampel dilakukan pada medium agar Muller-Hinton yang ditambah dengan $1 \mathrm{~mL}$ suspensi bakteri. Cakram kertas dengan konsentrasi 20.000 ppm untuk ekstrak kasar umbi sarang semut dan 2.000 ppm untuk klorheksidin diletakkan secara aseptik pada permukaan medium agar dan diinkubasi pada suhu $37^{\circ} \mathrm{C}$ selama 48 jam. Uji MIC dilakukan apabila pada uji Kirby-Bauer menunjukkan aktivitas antibakteri. Prosedur MIC yang dilakukan mempergunakan metode mikro dilusi yang kemudian diukur menggunakan ELISA Reader. Microplate steril yang terdiri atas 12 kolom dan 8 baris wells dipersiapkan.

Setiap kelompok sampel dilakukan pengujian pada satu lempeng microplate (Gambar 1). Setiap microplate terdiri atas 4 (empat) kelompok, yaitu kelompok media+sampel (baris AB), kelompok media+pelarut (baris CD), kelompok media+sampel+bakteri (baris EF), dan kelompok media+pelarut+bakteri (baris GH).

Untuk sampel ekstrak kasar dilakukan pada konsentrasi 5.000 ppm sehingga didapatkan hasil pengenceran sebesar $2.500 ; 1.250 ; 625 ; 312,5$; 156,$3 ; 78,13 ; 39,06 ; 19,53 ; 9,77 ; 4,88 ; 2,44$; dan 1,22 ppm. Untuk klorheksidin dilakukan pada konsentrasi 500 ppm sehingga didapatkan hasil pengenceran $250 ; 125 ; 62,5 ; 31,25 ; 15,63 ; 7,81$; 3,$91 ; 1,95 ; 0,98 ; 0,49 ; 0,2 ;$ dan 0,12 ppm.

Selanjutnya, microplate akan menerima sinar tampak $630 \mathrm{~nm}$ kemudian ELISA reader akan memberikan nilai optical density (OD) pada tiap well. Nilai MIC dari ekstrak kasar dan klorheksidin merupakan konsentrasi terkecil 


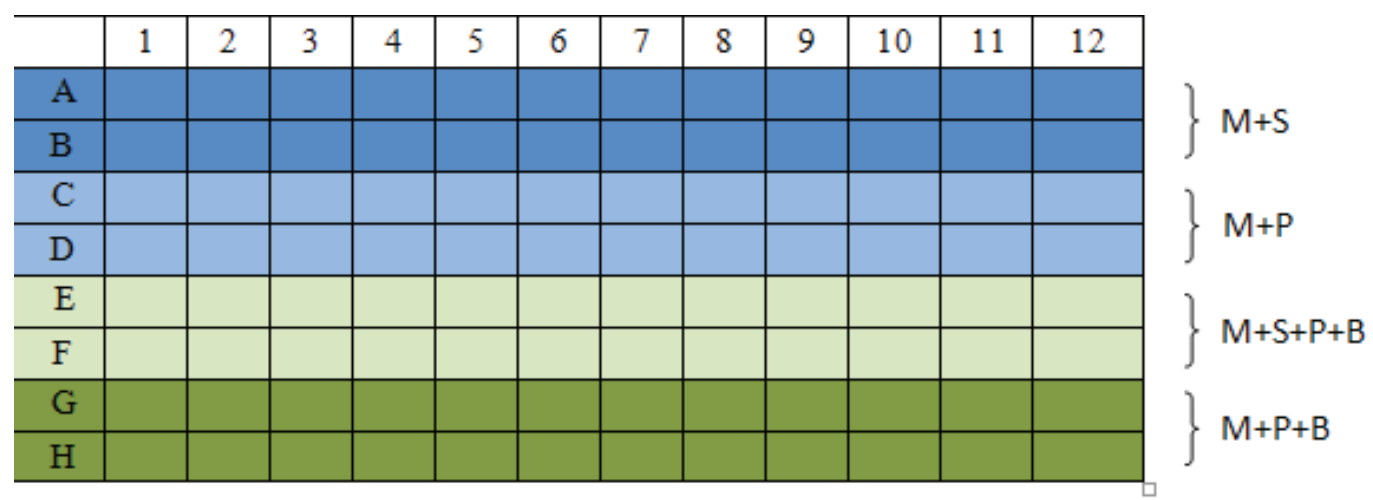

\section{Gambar 1 Lay Out MIC}

yang dapat membunuh 50\% populasi S. sanguis ATCC 10556 berdasarkan rumus:

$\%$ Penghambatan Bakteri $=\left[\frac{\left(O D_{M P B}-O D_{M P}\right)-\left(O D_{M S B}-O D_{M S}\right)}{\left(O D_{M P B}-O D_{M P}\right)}\right] \times 100$

Hasil uji Kirby-bauer dianalisis dengan cara statistik menggunakan uji Mann-whitney Data uji MIC diuji dengan uji ANOVA dan uji Tukey untuk mengetahui korelasi antara pemberian konsentrasi ekstrak kasar umbi sarang semut dan persentase kematian sel S. sanguinis. Mengukur kekuatan dan arah hubungannya digunakan analisis korelasi Pearson. Uji normalitas data dengan uji Kolmogrov-Smirnov. Analisis data penelitian diproses menggunakan program SPSS versi 20,0 .

\section{Hasil}

Klorheksidin dan ekstrak kasar umbi sarag semut menghasilkan zona hambat sebesar $15 \mathrm{~mm}$ dan $12 \mathrm{~mm}$ berturut-turut terhadap penghambatan pertumbuhan $S$. sanguinis (Tabel 1), oleh karena itu keduanya tergolong memiliki aktivitas antibakteri. Ekstrak kasar umbi sarang semut menghasilkan zona hambat lebih kecil daripada klorheksidin.

Perbedaan diameter hambat yang dihasilkan antara ekstrak kasar umbi sarang semut dan klorheksidin diuji dengan uji Mann-whitney (Gambar 2) . Ekstrak kasar umbi sarang semut dan kloheksidin menghasilkan diameter hambat yang tidak berbeda secara bermakna (12 mm vs. $15 \mathrm{~mm}$, $\mathrm{p}>0,05$ ).

Microplate ekstrak kasar umbi sarang semut pada kolom ke-1 sampai ke-6 pada baris AB dan EF memiliki warna yang pekat dan keruh. Hal ini memengaruhi perhitungan nilai persentase kematian sel bakteri. Karena penilaian visual pada microplate sulit dilakukan maka nilai MIC ditentukan melalui perhitungan nilai OD pada kolom ke-7 sampai 12 (Tabel 2). Perhitungan nilai OD akan menghasilkan nilai persentase kematian bakteri dari tiap kelompok konsentrasi.

Dari perhitungan pada tabel didapatkan nilai MIC ekstrak kasar umbi sarang semut yang dapat membunuh 50\% populasi Streptococcus sanguinis berada di antara pengenceran ke-9 $(9,77 \mathrm{ppm})$ dan ke-8 (19,53 ppm). Nilai MIC klorheksidin dari perhitungan persentase kematian sel (Tabel 3) didapatkan nilai MIC klorheksidin pada pengenceran ke-8 (1,953 ppm).

Untuk mengetahui hubungan dan besarnya

Tabel 1 Uji Kirby-Bauer terhadap S. sanguinis

\begin{tabular}{lcccc}
\hline \multirow{2}{*}{ Kelompok Sampel } & \multicolumn{3}{c}{ Diameter Hambat (mm) } & \multirow{2}{*}{ Keterangan } \\
\cline { 2 - 4 } & Uji I & Uji II & Rata-rata & Aktif \\
\hline Ekstrak kasar & 12,50 & 11,50 & 12,00 & Tidak aktif \\
Pelarut metanol & & & & Tidak aktif \\
Pelarut metanol air (1:1) & & & 15,00 & Aktif \\
Klorheksidin & 14,80 & 15,20 & & \\
\hline
\end{tabular}




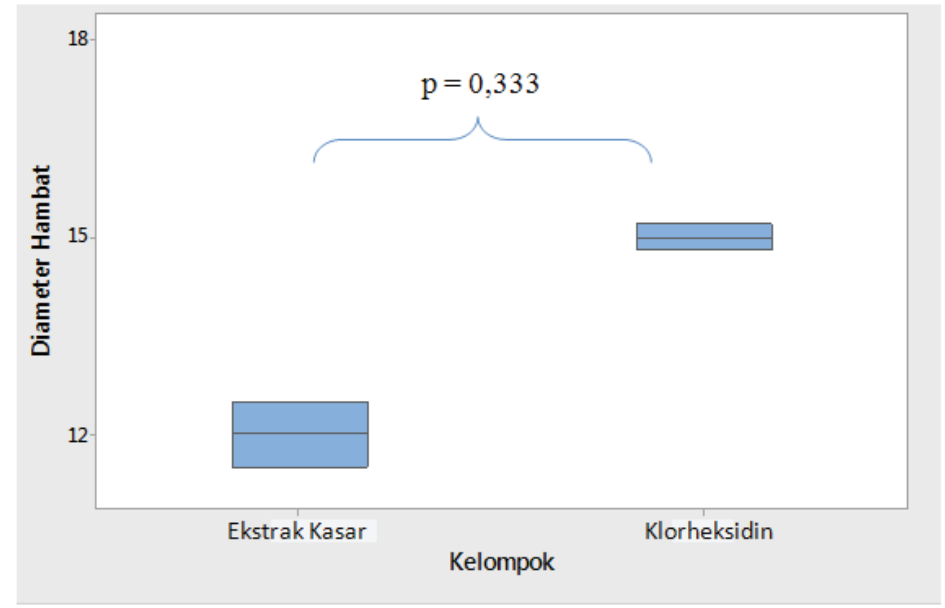

Gambar 2 Grafik Perbandingan Zona Hambat Ekstrak Kasar Umbi Sarang Semut dengan Klorheksidin

korelasi antara konsentrasi ekstrak kasar umbi sarang semut dan kematian sel bakteri perlu dilakukan uji ANOVA dan uji korelasi Pearson. Hasil uji ANOVA ekstrak kasar umbi sarang semut dilakukan pada konsentrasi 2,44; 4,88; 9,77; 19,53; dan 39,06 ppm terhadap persentase kematian sel bakteri S. sanguinis. Hasil pengujian pada derajat kepercayaan 95\% menunjukkan paling tidak satu perbedaan yang bermakna antara 5 kelompok konsentrasi, dilihat dari nilai $\mathrm{p}<0,01$. Oleh karena itu, untuk mengetahui perbedaan antara tiap-tiap perlakuan diperlukan uji Tukey.
Dari uji Tukey (Gambar 3) dapat diketahui nilai $\mathrm{p}<0,05$ antara ekstrak kasar dengan konsentrasi 2,44 ppm dan 19,53 serta 39,06 ppm terhadap persentase kematian sel bakteri. Pada konsentrasi 2,44 ppm ekstrak kasar umbi sarang semut dapat menyebabkan kematian sel bakteri sebesar $29,426 \%$, sedangkan persentase kematian sel S. sanguinis sebesar 50\% terdapat di antara konsentrasi 9,77 ppm dan 19,53 ppm. Kelompok konsentrasi 39,06 ppm menghasilkan persentase kematian sel bakteri yang paling tinggi apabila dibanding dengan kelompok lainnya. Dapat disimpulkan bahwa pemberian

Tabel 2 Hasil Analisis MIC Ekstrak Kasar Umbi Sarang Semut terhadap S. sanguinis

\begin{tabular}{|c|c|c|c|c|c|c|c|c|c|c|c|c|}
\hline \multirow{2}{*}{ Well } & \multicolumn{12}{|c|}{ Konsentrasi (ppm) } \\
\hline & 2.500 & 1.250 & 625 & 312,5 & 156,3 & 78,13 & 39.06 & 19.53 & 9.77 & 4.88 & 2.44 & 1.22 \\
\hline \multirow{2}{*}{$\begin{array}{l}\text { Media + } \\
\text { Sampel }\end{array}$} & 1,305 & 1,022 & 0,592 & 0,371 & 0,249 & 0,158 & 0,107 & 0,083 & 0,069 & 0,059 & 0,057 & 0,055 \\
\hline & 1,148 & 1,062 & 0,606 & 0,368 & 0,241 & 0,163 & 0,112 & 0,083 & 0,067 & 0,058 & 0,055 & 0,055 \\
\hline \multirow{2}{*}{$\begin{array}{l}\text { Media + } \\
\text { Pelarut }\end{array}$} & 0,089 & 0,064 & 0,058 & 0,055 & 0,054 & 0,059 & 0,057 & 0,054 & 0,055 & 0,053 & 0,053 & 0,053 \\
\hline & 0,068 & 0,063 & 0,057 & 0,055 & 0,053 & 0,054 & 0,055 & 0,053 & 0,054 & 0,053 & 0,055 & 0,054 \\
\hline $\begin{array}{l}\text { Media + } \\
\text { Sampel + }\end{array}$ & 1,053 & 0,978 & 0,599 & 0,362 & 0,243 & 0,145 & 0,102 & 0,085 & 0,075 & 0,069 & 0,07 & 0,069 \\
\hline Bakteri & 1,092 & 0,901 & 0,587 & 0,355 & 0,237 & 0,140 & 0,102 & 0,086 & 0,077 & 0,071 & 0,071 & 0,069 \\
\hline $\begin{array}{l}\text { Media + } \\
\text { Pelarut + }\end{array}$ & 0,067 & 0,067 & 0,057 & 0,057 & 0,065 & 0,061 & 0,063 & 0,067 & 0,069 & 0,071 & 0,072 & 0,073 \\
\hline Bakteri & 0,069 & 0,065 & 0,058 & 0,058 & 0,063 & 0,060 & 0,065 & 0,068 & 0,07 & 0,074 & 0,077 & 0,069 \\
\hline $\begin{array}{l}\% \\
\text { Kematian } \\
\text { Sel }\end{array}$ & - & - & - & - & - & - & 191,67 & 82,308 & 47,32 & 41,270 & 29,426 & 18,333 \\
\hline
\end{tabular}


Fathimah A.: Uji Aktivitas Antibakteri Ekstrak Kasar Umbi Sarang Semut (Myrmecodia pendens) Dibanding dengan Klorheksidin

Tabel 3 Hasil Analisis MIC Klorheksidin terhadap S. sanguinis

\begin{tabular}{|c|c|c|c|c|c|c|c|c|c|c|c|c|}
\hline \multirow{2}{*}{ Well } & \multicolumn{12}{|c|}{ Konsentrasi (ppm) } \\
\hline & 250 & 125 & 62,5 & 31,25 & 15,63 & 7,813 & 3,906 & 1,953 & 0,977 & 0,488 & 0,244 & 0,122 \\
\hline & 0,047 & 0,059 & 0,062 & 0,064 & 0,06 & 0,059 & 0,054 & 0,051 & 0,053 & 0,049 & 0,049 & 0,049 \\
\hline $\begin{array}{l}\text { Media + } \\
\text { Sampel }\end{array}$ & 0,05 & 0,056 & 0,059 & 0,059 & 0,057 & 0,054 & 0,052 & 0,05 & 0,05 & 0,047 & 0,048 & 0,05 \\
\hline & 0,047 & 0,048 & 0,047 & 0,049 & 0,05 & 0,044 & 0,049 & 0,044 & 0,046 & 0,045 & 0,047 & 0,049 \\
\hline Pelarut & 0,045 & 0,045 & 0,047 & 0,047 & 0,046 & 0,048 & 0,047 & 0,047 & 0,046 & 0,047 & 0,047 & 0,05 \\
\hline Media + & 0,055 & 0,06 & 0,064 & 0,063 & 0,058 & 0,054 & 0,053 & 0,049 & 0,074 & 0,066 & 0,067 & 0,064 \\
\hline Bakteri & 0,055 & 0,059 & 0,063 & 0,062 & 0,056 & 0,053 & 0,051 & 0,049 & 0,073 & 0,064 & 0,063 & 0,067 \\
\hline $\begin{array}{l}\text { Media + } \\
\text { Pelarut + }\end{array}$ & 0,059 & 0,062 & 0,062 & 0,062 & 0,061 & 0,059 & 0,06 & 0,06 & 0,061 & 0,06 & 0,061 & 0,063 \\
\hline Bakteri & 0,059 & 0,063 & 0,061 & 0,063 & 0,062 & 0,063 & 0,063 & 0,064 & 0,062 & 0,063 & 0,063 & 0,064 \\
\hline $\begin{array}{l}\% \\
\text { Kematian } \\
\text { Sel }\end{array}$ & 48,81 & 88,095 & 79,048 & 94,471 & 112,216 & 120 & 107,670 & 109,191 & $-41,875$ & $-9,792$ & $-11,161$ & $-14,286$ \\
\hline
\end{tabular}

konsentrasi ekstrak kasar umbi sarang semut berpengaruh terhadap kematian sel bakteri $S$. sanguinis.

Untuk mengetahui besar dan arah korelasi pemberian konsentrasi ekstrak kasar umbi sarang semut dengan kematian sel S. sanguinis perlu dilakukan uji korelasi. Nilai koefisien korelasi (r) yang didapat sebesar 0,867 yang berarti terdapat hubungan yang kuat dan positif antara konsentrasi ekstrak kasar umbi sarang semut terhadap kematian sel bakteri. Simpulan, semakin besar konsentrasi ekstrak kasar yang diberikan maka semakin besar pula daya bunuh terhadap sel S. sanguinis. Hal ini mengindikasikan bahwa ekstrak kasar umbi sarang semut sebagai antibakteri yang bersifat concentration-dependent.

\section{Pembahasan}

Hasil penelitian ini menunjukkan bahwa ekstrak kasar umbi sarang semut pada konsentrasi 20.000 ppm memiliki efek antibakteri yang tidak berbeda secara signifikan dengan klorheksidin (12 mm vs $15 \mathrm{~mm}, \mathrm{p}>0,05)$. Hasil

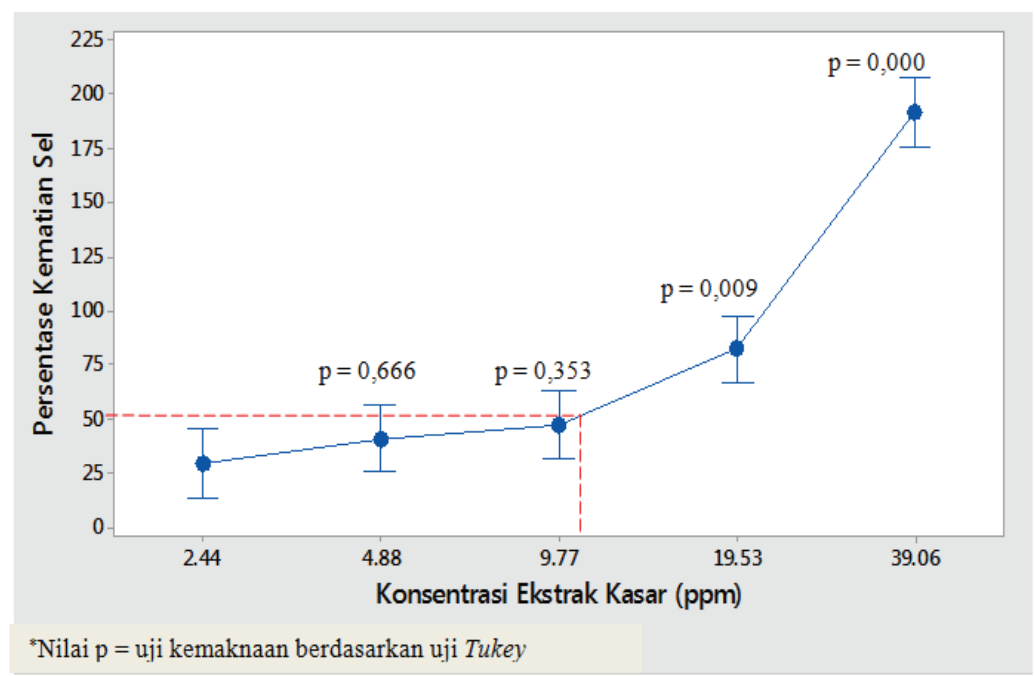

\section{Gambar 3 Grafik Perbedaan Persentase Kematian Sel antara Konsentrasi Ekstrak Kasar Umbi Sarang Semut}


uji MIC menunjukkan nilai MIC ekstrak kasar umbi sarang semut berada di antara 9,77 ppm dan 19, 53 ppm dan klorheksidin 1,953 ppm. Dapat diasumsikan bahwa efek antibakteri yang dimiliki ekstrak kasar umbi sarang semut lebih kecil daripada klorheksidin.

Dalam ekstrak tanaman herbal terdapat sifat endointeraksi, yaitu interaksi yang terjadi di antara banyak senyawa yang terdapat di dalam ekstrak sehingga terjadi modifikasi sifat farmakologis dari senyawa tersebut. Sistem biologi memfasilitasi efek sinergistik dari banyak senyawa pada tanaman herbal. ${ }^{8}$ Endointeraksi yang terdapat pada ekstrak kasar umbi sarang semut memperlihatkan potensiasi senyawasenyawa yang terdapat di dalamnya.

Hasil uji MIC menunjukkan ekstrak kasar dan klorheksidin memiliki aktivitas bakteriostatik terhadap bakteri S. sanguinis ATCC 10556, dengan konsentrasi minimum di antara 9,77 ppm dan 19,53 ppm untuk ekstrak kasar umbi sarang semut dan 1,953 ppm untuk klorheksidin. Pada konsentrasi 2,44 ppm ekstrak kasar umbi sarang semut menyebabkan kematian sel di atas $20 \%$, sedangkan untuk dapat menyebabkan $50 \%$ kematian sel pada populasi bakteri uji dibutuhkan konsentrasi di antara 9,77 ppm dan 19,53 ppm.

Berdasar atas uji MIC, diketahui ekstrak kasar tergolong antibakteri bersifat concentrationdependent. Antibakteri golongan ini memiliki perbedaan antara efek maksimum dan efek minimum relatif besar dan dengan peningkatan konsentrasi akan meningkatkan kemampuan bunuh terhadap bakteri. ${ }^{9}$ Efek antibakteri yang optimal dari antibakteri concentrationdependent bergantung pada luas area di bawah kurva penghambatan yang disederhanakan menjadi rasio antara konsentrasi optimal bila dibanding dengan MIC antibakteri tersebut. ${ }^{10}$

Pada penelitian ini diketahui efek antibakteri paling optimal dihasilkan pada konsentrasi 39,06 ppm. Hal ini belum dapat dipastikan karena pada penelitian ini pengujian konsentrasi di atas 39,06 ppm, yaitu pada konsentrasi 78,13 ppm dipengaruhi oleh sifat kekeruhan yang dimiliki oleh ekstrak kasar sehingga perhitungan persentase kematian sel bakteri tidak dapat dilakukan. Oleh karena itu, perlu dilakukan penelitian yang lebih lanjut untuk mengetahui konsentrasi optimal yang dibutuhkan untuk dapat membunuh bakteri S. sanguinis. Selain itu, perlu diuji efek toksisitasnya untuk mengetahui efek samping yang dapat ditimbulkan dan konsentrasi minimum yang dapat menyebabkan kematian pada $50 \%$ populasi hewan coba. ${ }^{29}$
Standar Meyer menyatakan bahwa suatu zat tergolong toksik apabilla memiliki nilai $\mathrm{LC}_{50}$ $<1.000 \mu \mathrm{g} / \mathrm{mL}$ untuk ekstrak. ${ }^{11}$ Uji toksisitas ekstrak etanol sarang semut terhadap mencit Swiss memiliki nilai $\mathrm{LD}_{50} 3.162 \mathrm{~g} / \mathrm{kg}$ dan uji toksisitas ekstrak air sarang semut terhadap mencit mempunyai $\mathrm{LD}_{50} 3.750 \mathrm{mg} / \mathrm{kg} .12,13$ Klorheksidin memiliki nilai $\mathrm{LD}_{50} 2.515 \mathrm{mg} /$ kg pada mencit Alderly Park jantan. ${ }^{14}$ Dapat disimpulkan bahwa ekstrak umbi sarang semut memiliki toksisitas yang lebih kecil daripada klorheksidin. Namun, sebaiknya dilakukan studi toksisitas kronik untuk ekstrak kasar umbi sarang semut.

Mekanisme kerja yang dimiliki oleh tanaman herbal lebih mengarah pada aktivasi self-healing dan proteksi tubuh manusia (terutama sistem imunitas), meningkatkan keseimbangan regulasi tubuh dan menghancurkan patogen tanpa efek samping maupun toksisitas. Ekstrak, fraksi, maupun isolat umbi sarang semut telah terbukti selain mempunyai aktivitas antibakteri juga memiliki aktivitas antioksidan, imun modulator, dan antikanker. ${ }^{6,15}$

Nilai MIC ekstrak kasar umbi sarang semut berada di antara 9,77 ppm dan 19,53 ppm apabila dibanding dengan klorheksidin 1,953 ppm memiliki rentang yang tidak terlalu jauh, meskipun zona hambat yang dihasilkan masih lebih rendah dibanding dengan klorheksidin. Apabila dibandingkan dengan ekstrak metanol jambu biji (Psidium guajava) yang memiliki nilai MIC $1 \mathrm{mg} / \mathrm{mL}$ dan ekstrak kelopak delima (Punica granatum) yang memiliki nilai 7,81 mg/ $\mathrm{mL}$, ekstrak kasar umbi sarang semut memiliki efek antibakteri yang lebih signifikan dalam menghambat pertumbuhan $S$. sanguinis. ${ }^{16,17}$ Ekstrak kasar umbi sarang semut memiliki efek antibakteri yang lebih baik dalam menghambat $S$. sanguinis apabila dibanding dengan ekstrak tumbuhan lainnya.

Efek biologis yang dimiliki oleh ekstrak kasar umbi sarang semut yang bersumber dari tanaman herbal masih dapat ditingkatkan. Kombinasi ekstrak tumbuhan dan mineral dapat meningkatkan aktivitas antibakteri ekstrak tersebut. Ekstrak pomegrante dan mineral $\mathrm{CuSO}_{4}$ dapat menurunkan 4.0 log MRSA. Penelitian lainnya membuktikan bahwa penambahan ion logam pada ekstrak vanilin dapat meningkatkan efek antibakteri pada bakteri $S$. aureus, E. coli, $K$. pneumoniae, $P$. vulgaris, $P$. aeruginosa, dan C. albicans. ${ }^{18}$ Aktivitas antibakteri tanaman yang mengandung senyawa fenol, seperti umbi sarang semut dapat ditingkatkan, yaitu mengombinasikan ekstraknya dengan $\mathrm{Cu}^{2+}$ atau 
vitamin C. $^{19}$ Oleh karena itu, perlu dilakukan penelitian lebih lanjut mengenai penggunaan mineral sebagai unsur tambahan untuk dapat meningkatkan aktivitas antibakteri ekstrak kasar umbi sarang semut.

Melalui penelitian ini dapat disimpulkan bahwa efek antibakteri ekstrak kasar umbi sarang semut lebih rendah apabila dibanding dengan dengan klorheksidin, tetapi ekstrak kasar memiliki keunggulan lain. Efek antibakteri yang dimiliki oleh ekstrak kasar dapat ditingkatkan dengan mengombinasikannya dengan mineral. Kemudian, ekstrak kasar memiliki nilai $\mathrm{LD}_{50}$ yang lebih besar daripada klorheksidin, sebagai indikator toksisitas. Ekstrak kasar umbi sarang semut dapat dipergunakan dalam jangka waktu lama. Selain efek antibakteri, ekstrak kasar umbi sarang semut juga memiliki efek biologis lain yang dapat menunjang kemampuan antibakteri. Sifat antibakteri ekstrak kasar umbi sarang semut lebih tinggi dibanding beberapa tumbuhan alam lainnya.

\section{Daftar Pustaka}

1. Lockhart PB, Bolger AF, Papapanou $\mathrm{PN}$, Osinbowale $\mathrm{O}$, Trevisan $\mathrm{M}$, Levison ME, dkk. Periodontal disease and atherosclerotic vascular disease: does the evidence support an independent association? A scientific statement from the American Heart Association. Circulation. 2012;125(20):2520-44.

2. Xu P, Alves JM, Kitten T, Brown A, Chen Z, Ozaki LS, dkk. Genome of the opportunistic pathogen Streptococcus sanguinis. J Bacteriol. 2007;189(8):3166-75.

3. Ge X, Kitten T, Chen Z, Lee SP, Munro CL, Xu P. Identification of Streptococcus sanguinis genes required for biofilm formation and examination of their role in endocarditis virulence. Infect Immunol. 2008;76(6):2551-9.

4. Okahashi N, Nakata M, Terao Y, Isoda R, Sakurai A, Sumitomo T, dkk. Pili of oral Streptococcus sanguinis bind to salivary amylase and promote the biofilm formation. Microb Pathog. 2011;50(3):148-54.

5. DuttP, Rathore PK, Khurana D. ChlorhexidineAn antiseptic in periodontics. IOSR-JDMS. 2014;13(9):85-8.

6. Hamsar M, Mizaton H. Potential of ant-nest plants as an alternative cancer treatment. J Pharm Res. 2012;5(6):3063-6.

7. Setyani W. Isolasi dan identifikasi senyawa antimikroba dari umbi sarang semut (Myrmecodia tuberosa (non Jack.) BI) [tesis]. Yogyakarta: Universitas Gadjah Mada; 2011.

8. Efferth T, Koch E. Complex interactions between phytochemicals. The multi-target therapeutic concept of phytotherapy. Curr Drug Targets. 2011;12(1):122-32.

9. Abdul-Aziz MH, Lipman J, Mouton JW, Hope WW, Roberts JA. Applying pharmacokinetic/ pharmacodynamic principles in critically ill patients: optimizing efficacy and reducing resistance development. Semin Respir Crit Care Med. 2015;36(1):136-53.

10. Richards G, Joubert I, Brink A. Optimising the administration of antibiotics in critically ill patients: continuing medical educationarticle. S Afr Med J. 2015;105(5):419-24.

11. Supriatno. Antitumor activity of Papua's Myrmecodia pendans in human oral tongue squamous cell carcinoma cell line through induction of cyclin-dependent kinase inhibitor p27Kip1 and suppression of cyclin E. J Cancer Res Ther. 2014;2:48-53.

12. Pandia DMH, Wibriansyah A, Pratiwi W, Priadinata AF, Sari W. Uji toksisitas akut ekstrak etanol sarang semut (myrmecodia pendens) Kalimantan pada mencit (Mus musculus) Swiss. Majalah Kesehatan Pharmamedika. 2012;3(1):1-5;

13. Soeksmanto A, Simanjuntak P, Subroto MA. Uji toksisitas akut ekstrak air tanaman sarang semut (myrmecodia pendans) terhadap histologi organ hati mencit. Jurnal Natur Indonesia. 2010;12(2):152-5.

14. Woodward K. Veterinary pharmacovigilance. Part 4. Adverse reactions in humans to veterinary medicinal products. J Vet Pharmacol Ther. 2005;28(2):185-201.

15. Engida AM, Kasim NS, Tsigie YA, Ismadji S, Huynh LH, Ju Y-H. Extraction, identification and quantitative HPLC analysis of flavonoids from sarang semut (Myrmecodia pendan). Industrial Crops Products. 2013;41:392-6.

16. Hajifattahi F, Moravej-Salehi E, Taheri M, Mahboubi A, Kamalinejad M. Antibacterial Effect of hydroalcoholic extract of punica granatum Linn. Petal on common oral microorganisms. Int J Biomaterials. 2016; 2016(2):1-6.

17. Razak FA, Othman RY, Rahim ZHA. The effect of Piper betle and Psidium guajava extracts on the cell-surface hydrophobicity of selected early settlers of dental plaque. J Oral Sci. 2006;48(2):71-5.

18. Nair MS, Joseyphus RS. Synthesis and characterization of $\mathrm{Co}$ (II), Ni (II), Cu (II) 
and Zn (II) complexes of tridentate Schiff base derived from vanillin and DL- $\alpha$ aminobutyric acid. Spectrochimica Acta Part A: Molecular Biomolecular Spectroscopy. 2008;70(4):749-53.
19. Iwasaki $Y$, Hirasawa T, Maruyama $Y$, Ishii Y, Ito R, Saito K, dkk. Effect of interaction between phenolic compounds and copper ion on antioxidant and pro-oxidant activities. Toxicol In Vitro. 2011;25(7):1320-7. 